\title{
The News of Empire: Telegraphy, Journalism and the Politics of Reporting in Colonial India
}

Review Number: 2149

Publish date: Thursday, 10 August, 2017

Author: Amelia Bonea

ISBN: 9780199467129

Date of Publication: 2016

Price: $£ 27.68$

Pages: 400pp.

Publisher: Oxford University Press

Place of Publication: India

Reviewer: Anindita Ghosh

Amelia Bonea has presented a timely book that combines the mechanisms of technology and news making in critically meaningful ways to present the production of printed news as contingent, variable and even accidental. It examines particularly the role that the telegraph played in changing the landscape for the circulation of news in colonial India and promoting certain journalistic practices and visions that emerged with this technology within English language journalism.

The overwhelming trend in the historiography of newspapers in South Asia has been to treat 'the press' as solely identifiable with the finished product of the printed newspapers. This has led to closely written histories of the published content of the individual news presses, and their editorial management. But what comes into play before the news is actually 'made'? What processes determine the flow of news? Which pieces of news make it to the printed page and why? How far can technology enable news making and how does it sit alongside more traditional means of news accumulation in India? The book answers these questions and many more. It looks into the worlds of journalism and politics of news reporting during a relatively unknown but formative period in the history of the newspaper press in South Asia, when the more familiar histories of the nationalist press were not operative.

The potential archive here was vast, with 421 English language and vernacular newspapers being published in British India and the princely states in 1885 alone (p. 26). Bonea chose therefore to be guided by the narrative of telegraphy, selecting major English language newspapers which were most directly affected by the technology at this time. The critical dates in the history of telegraphy also form key reference points from the opening of the Indian telegraphs for public use in 1855, to the facilitation of the Red Sea Route in 1870 - with the book finally stopping short of the introduction of wireless telegraphy in 1900. There are five chapters in the book organised in a practical manner, with three chapters out of five (chapters one, two and four) dealing exclusively with telegraphic news, while the two others [three and five] explore the world of 19th-century journalism in South Asia within which telegraphy is to be located. The News of Empire approaches the research through three principal methodological routes: that of geography - the news pathways and channels of communication; that of technology - the social, political and cultural contexts and ramifications of telegraphy; and that of reporting/journalism - the processes of news making, explored through specific instances of news reporting. In addition to the obvious source of newspapers, the book uses 
the Reuters archives as well as a host of government records, reports and other printed sources.

The book provides a fascinating description of the material culture of telegraphy, with the most captivating accounts of the transmission of news: from London to India and vice versa. Telegraphic intelligence reached Bombay from London via the sea route. The initial message went via land cable from London to Cornwall where it was read by a siphon recorder. The message was then re-punched for transmission to Gibraltar, where an operator acting as a 'human relay' simultaneously read and re-sent it to Alexandria via Malta. At Alexandria it was written on slips of paper and retransmitted over land cables to the Suez, from where it was forwarded to Aden, where a 'human relay' intervened once again, helping it on its final journey over the 2,000-mile-long submarine cable to Bombay. Once overseas news reached India, it was rapidly distributed by the Telegraph Department to various parts of the country via 'news bulletins'. These were published for free at the main telegraphic centres - Calcutta, Madras, Agra and Lahore, as well as other repeating stations using Morse technology. But while free, the dissemination of telegraphic news was hierarchical, not only being limited to the suitably equipped centres but also being available solely to those newspapers 'of sufficient standing and circulation to render the communication of intelligence to them a real convenience to the community' (pp. 175-6). It also tells us of an interconnected press world, joined up not just by technology but also personnel - where the same person often straddled the line between journalist-editor and printer-proprietor, and worked for a number of newspapers both in India and Britain - and standardised reporting practices.

While Bonea does not dispute the importance of telegraphy for the world of 19th-century journalism, she is keen to point out its limitations. The telegraph did not immediately revolutionise news, the book argues. Its absorption was halting and imperfect, given over to the vagaries of nature, malpractice and ignorance alike. Thus in its early days only one in four telegraphic messages was correctly transmitted (p. 97), messages became abridged during transmission and even misread (p. 298). The work here is in line with more recent histories of technology such as David Arnold's recent book on everyday technology - a critical work which should have been mentioned here - which showcases the smaller stories of the typewriter, bicycle and sewing machine which impacted Indian lives in incremental ways, taking the focus away from the big stories of modernisation and change.(1) Bonea also suggests we place the telegraph alongside older modes of communication such as steamers, carts and even carrier pigeons (chapter one). Again this is something that Arnold has already explored, for instance with regard to the context of traffic in urban colonial India, where the impact of fast moving motor cars was considerably impeded by the simultaneous presence of pedestrians, pack animals and plodding bullock carts on the city streets.(2) In fact, the technical shortcomings of telegraph have been pointed out before, and are directly acknowledged in the book (p. 23).

The other part of the technological narrative is located in the social and cultural history of telegraphy and journalism in India (in chapters two and three). Chapter two asks how telegraphy was mediated by a myriad of social and cultural contexts, and in turn shaped people's imaginations about modernity. Although it does not quite manage to deliver the goods promised - as inevitably vernacular responses to telegraphy would remain locked in vernacular sources, a category not explored here - the glimpses it provides, e.g. a tribal song on telegraphy (p. 122) are nevertheless rich in the possibilities they suggest.

What is of greater significance, and comes out clearly in the book, is the location of telegraphy within a complex political economy of circulation of news, and journalistic practices. Where Bonea adds substantially to existing works is in her painstaking recovery of this context of telegraphy for 19th-century journalism. In suggesting informational hierarchies - as between Home (news from Britain and Europe) news and India news, the predominance of commercial news networks, and preferred practices in selection, spread and layout of telegraphic news in newspapers, she shows telegraphy's adoption as a mode of communication in the world of journalism as piecemeal and gradual. The political context of dissemination of news - the role of the colonial state - also sufficiently impeded the neutral production of knowledge via technology. While telegraph engineers hailed telegraphy as 'the great revolution', journalists noted its restricted use owing to high costs until the last two decades of the 19th century (p. 166). 
I think the real strengths of the book lies in its recreation of the world of 19th-century journalism. Chapter three in particular opens out the world of news making in terms of bringing alive the granular world of printer-publishers, technicians, and newsmen. The chapter locates telegraphy within the broader processes of communication, journalism and news reporting in colonial India to assess its place in contemporary news making. Journalism, Bonea tells us, was an 'occupation' not a 'profession' in 19th-century India. It was badly paid, and therefore had to be carried on alongside other jobs or through multiple journalistic contracts. Neither did it earn much respect. European journalists were distrusted for their potential to publicise scandals and for fear of political criticism, while most newspapers were seen as provincial in their scope. In addition there existed hierarchies between 'Home' and English run newspapers in India, Anglo-Indian and English language Indian papers, and the English language and vernacular presses. The attitude to the vernacular press can be summed up in a contemporary comment that compared it to the cicada: making noise 'out of all proportions to its size and consequence' (p. 155). The sharp remark was aimed at anti-colonial sentiments being vociferously expressed in these newspapers. Where the book genuinely makes fascinating contribution is to bring alive this world of the pre-nationalist phase of printing when newspapers had a different role to play and journalism was less led by a singular objective such as that of nationalism. In many ways this was the world of news and newspapers in the making.

The best part, however, is reserved for the end. The two case studies - that of the Austro-Prussian Was of 1866 and the assassination of the Plague Commissioner, W. C. Rand at Poona in 1897 - studied in the last chapter offer a close profile of this world. It shows how the two major Anglo-Indian newspapers under focus here - the Bombay Gazette and the Englishman - were shaped as much by colonial control and economic considerations as the personal visions of editors, proprietors and printers. The case studies also highlight both the advantages (timely access of news) and the pitfalls (mistakes in reporting, absence of sufficient detail) of telegraphy as technology. But the rich wealth of information here on the scope of telegraphic news within the world of journalism, their flows across land and sea, the layout of the telegraphic features and advertising (and here is a story yet to be told), shipping news, and the politics of reporting paints a rich tapestry of the news scene in South Asia in the 19th century. The space occupied by domestic news in relation to foreign news is of interest. According to Bonea, prior to the 1880s (thanks to lower rates) there was much domestic telegraphic news, most of which concerned itself with shipping and commercial intelligence. Although political news had featured in the 1850s - and no doubt would have been important around 1857 at the time of the Rebellion - they declined during the two decades following. By contrast, the post 1880 s period had much more political news to present. The nodes of overland communication in the sub-continent were good indicators of the politics and nature of news transmitted. Thus the Englishman had its news coming from Simla, the summer capital, whereas for the Bombay Gazette, Poona and Allahabad, in addition to Simla, supplied news.

Chapter four highlights the expansion of Reuters in India, and the resulting commodification of news that engendered its protection through copyright. It also examines the relationship between the colonial state, Reuters, and the newspaper press in 19th-century India, showing how official visions of news and reporting sat alongside, clashed with and/or circumscribed alternative visions championed by journalists and Reuters. Mechanisms of colonial control ranged from the supply of official gazettes containing 'approved' news to Editors Rooms to draconian press regulations. But the assumptions of control are a bit thinly stretched here and to a certain extent a reflection of the limitations of an English-language-newspaper source base. The critical literature on censorship does not bear this out, nor do the production and reading practices of vernacular newspapers. The 19th-century print world was too flexible and innovative to be trapped by censorship and knew how to sidestep official regulations, often with great dexterity. Historians such as Robert Darnton have shown how slippery the hand of control was when it came to censoring - especially how news could fall in between the cracks of the oral and written - while the story of the very vocal and nationalist Amrita Bazar Patrika changing its medium from vernacular to English overnight to escape the clutches of the draconian 1878 Vernacular Press Act is too well known to merit repetition here.(3)

This brings me to the point of readership. As Bonea points out, the primary audience for the newspapers 
under focus was 'a relatively small group of Anglo-Indian merchants, soldiers, administrators, and other civilians resident in the subcontinent as well as a growing group of English-educated Indians ...' (p. 3). Such news was in high demand among these audiences, particularly the mercantile community and the competition to get to the latest intelligence was so acute that press telegrams were allegedly trafficked by newspapers (p. 189). The 'rush for news' at the Colombo post-office shows how eagerly news from home was awaited by colonials in India (p. 165). But vernacular newspapers lent themselves to a different pace of leisurely, collective reading, a collaborative enterprise between readers and listeners. Initial vernacular newspapers were weeklies, with dailies materialising in the early 19th century.

The book, however, is ambitious in its scope when it declares its intention to engage with the additional nonprint world in which news circulated, including the oral culture of reading aloud. But the phenomenon of oral cultures interacting with the world of print has been examined in depth before.(4) The strength of the 19th-century print-cultures, it has been argued, rested on their willingness to be malleable, to adapt to the ways of oral cultures initially and allow for residual pre-print practices to continue in the writing, production and consumption of print.(5) The News of Empire does not really add much to this literature, in methodology or perspective, particularly because the vast world of vernacular newspapers remains beyond its scope. What I would have really liked to see are the specific instances of orality shaping the specific cultures of news reading and circulation. Was this interaction with news different from that with books? Did reading aloud change the material layout of the reading matter (e.g. was the fifth page read before the first?)? And how far in that sense did the reader shape the reading/listening experience of the audience? What about the emotive intervention of the reader, and to what extent did it alter the prioritisation of news as intended by the editor?

This is a rich and informative book that opens out the way for further and interesting research into telegraphy and journalism in the 19th century. Ironically, where it excels is an area that I thought was underemphasized in the book - the material culture of news and news making - rather than in its stated objectives of outlining the interconnected story of technology, modernity and print-culture.

\section{Notes}

1. David Arnold, Everyday Technology: Machines and the Making of India's Modernity (Chicago, London, 2013). Back to (1)

2. David Arnold, 'The problem of traffic: the street life of modernity in late colonial India', Modern Asian Studies, 46, special issue 1 (January 2012), 119-41.Back to (2)

3. Robert Darnton, 'Literary surveillance in the British Raj: the contradictions of liberal imperialism', Book History, 4 (2001), 133-76.Back to (3)

4. Anindita Ghosh, Power in Print: Popular Publishing and the Politics of Language and Culture in a Colonial Society (New Delhi, 2006); Isabel Hofmeyr, Gandhi's Printing Press: Experiments in Slow Reading (Harvard, MA, 2013); Miles Ogborn, Indian Ink: Script and Print in the Making of the English East India Company (Chicago, IL, 2008). Back to (4)

5. Anindita Ghosh, 'An uncertain "Coming of the Book": early print cultures in colonial India', Book History, 6, 1 (2003), 23-55. Back to (5)

Source URL:https://reviews.history.ac.uk/review/2149

\section{Links}

[1] https://reviews.history.ac.uk/item/264288 